\title{
Non-communicable diseases and preventive health behaviors: a comparison of Hispanics nationally and those living along the US-Mexico border
}

\author{
Belinda M. Reininger ${ }^{1 *}$, Jing Wang ${ }^{2}$, Susan P. Fisher-Hoch ${ }^{1}$, Alycia Boutte ${ }^{3}$, Kristina Vatcheva ${ }^{1}$ \\ and Joseph B. McCormick
}

\begin{abstract}
Background: Non-communicable diseases (NCDs) are rising among US Hispanics, but few studies have examined the preventive health behaviors for these NCDs among Hispanics. This study compared the preventive health behaviors of smoke-free living, physical activity, fruit and vegetable consumption, and avoidance of heavy alcohol use in Hispanics in the United States and Hispanics living along the US-Mexico border.

Methods: Two weighted data sets with information on Hispanic populations were analyzed: 1) the national Behavioral Risk Factor Surveillance Survey $(n=29,942)$ from 2009; and 2) the Cameron County Hispanic Cohort $(n=1,439)$ recruited from the US-Mexico border between 2008-2011. To compare the preventive health behaviors of the samples, within a generalized estimating equation framework, weighted univariate and multivariate logistic regression analyses were conducted controlling for age, educational attainment, employment, language, and insurance status. Statistical tests were two-sided with a significance level set at 0.05 .

Results: Both samples reported low engagement in preventive behaviors. However, Hispanic males and females from the US-Mexico border were significantly less likely than the national sample to meet physical activity and fruit and vegetable consumption guidelines. Also, Hispanic males from the US-Mexico border were more likely to engage in heavy alcohol use.
\end{abstract}

Conclusion: The lack of preventive health behaviors among Hispanics living along the US-Mexico border presents a dire prospect for NCD control in the region. Multipronged approaches to address multiple behaviors should be considered.

Keywords: Hispanics, Non-communicable diseases, Preventive health behaviors, US-Mexico border

\section{Background}

The burgeoning of non-communicable diseases (NCDs) worldwide brings a growing threat to public health and to economies: costs are projected to exceed $\$ 30$ trillion over the next 20 years $[1,2]$. NCDs now account for more than two-thirds of deaths globally [3], and in the United States (US), NCDs including cardiovascular disease, cancer, chronic respiratory disease and diabetes,

\footnotetext{
*Correspondence: Belinda.M.Reininger@uth.tmc.edu

'University of Texas Health Science Center - School of Public Health, Brownsville Regional Campus, One West University Blvd, RAHC, Brownsville, TX 78520, USA

Full list of author information is available at the end of the article
}

contribute to 7 out of 10 deaths $[1,4,5]$. NCDs also disproportionately affect low-income and minority populations in the US [6]. They are pronounced among Mexican Americans, especially those living along the US-Mexico border, the geographical region extending north from Mexico into the US for $100 \mathrm{~km}$ [7]. Recent research shows that Hispanics living along the USMexico border experience levels of NCDs resembling the morbidity and mortality rates found in low-and middle-income countries $[1,8]$.

NCDs are among the most preventable of diseases, primarily because they are a result of individual health behaviors [4]. Preventive health behaviors, including

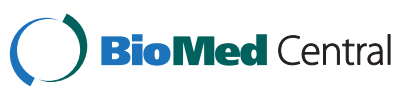


smoke-free living, physical activity, fruit and vegetable consumption, and avoidance of heavy alcohol use, help to prevent or alleviate the suffering and early mortality related to NCDs [4] (see Table 1). It is estimated that if behavioral and environmental risks associated with NCDs were removed it is estimated that at least $80 \%$ of all heart disease, stroke, and Type II diabetes and more than $40 \%$ of cancer cases could be prevented [9]. However, little research examined behaviors preventive of NCDs among Hispanics, particularly along the US-Mexico border. This study therefore examined the extent to which preventive health behaviors were self-reported among Hispanics, primarily of Mexican descent, in two weighted samples, one from the US as a whole and the other from the USMexico border. Given the documented chronic disease prevalence along the border, we expected to see fewer preventive health behaviors, including smoke-free living, physical activity, fruit and vegetable consumption, and avoidance of heavy alcohol use in Hispanics living along the border than in Hispanics nationally.

\section{Methods}

The study used two datasets containing detailed information on Hispanic populations. One sample included 29,942 Hispanic respondents from the national Behavioral Risk Factor Surveillance System (BRFSS) in 2009 [10]. The other sample included a total of 1,408 participants from the Cameron County Hispanic Cohort (CCHC) who were enrolled between the years 2008 and 2011 [11].

Table 1 Guidelines and data on preventive health behaviors associated with non-communicable diseases (NCDS)

\begin{tabular}{|c|c|}
\hline Behavior & Guidelines and Facts \\
\hline \multirow[t]{3}{*}{ Smoke-free Living } & $\begin{array}{l}\text { - The Surgeon General's report indicates that there is no acceptable level of exposure to cigarette smoke. } \\
\text { Cigarette use is the most preventable source of disability, disease, and death in the US [36]. }\end{array}$ \\
\hline & $\begin{array}{l}\text { - Approximately } 4 \text { of } 5 \text { American adults are current non-smokers. However, about } 43 \text { million American adults } \\
\text { currently smoke [4], and an estimated } 443,000 \text { people die prematurely each year from smoking or } \\
\text { exposure to secondhand smoke [40]. }\end{array}$ \\
\hline & $\begin{array}{l}\text { - Approximately } 84 \% \text { of US Hispanic adults report not smoking, compared to } 78 \% \text { of non-Hispanic } \\
\text { whites [41]. }\end{array}$ \\
\hline \multirow[t]{4}{*}{ Physical Activity } & $\begin{array}{l}\text { - The US Department of Health and Human Services (DHHS) recommends that adults complete } 150 \text { minutes } \\
\text { of moderate-intensity activity or } 75 \text { minutes of vigorous-intensity activity per week [42]. }\end{array}$ \\
\hline & $\begin{array}{l}\text { - Physical activity has numerous health benefits, particularly related to achieving and maintaining a } \\
\text { healthy weight which reduces risks for NCDs [43]. }\end{array}$ \\
\hline & $\begin{array}{l}\text { - Based on the DHHS } 2008 \text { Physical Activity Guidelines for Americans, less than two-third of all adults } \\
\text { meet physical activity recommendations [42]. }\end{array}$ \\
\hline & - Hispanics nationally are less likely to be physically active than their non-Hispanic White counterparts [29, 31-33]. \\
\hline \multirow[t]{6}{*}{ Fruit and Vegetable Consumption } & $\begin{array}{l}\text { - Men aged between 31-50 years should consume approximately } 2 \text { cups of fruit and } 3 \text { cups of } \\
\text { vegetables per day [19]. }\end{array}$ \\
\hline & $\begin{array}{l}\text { - Women aged between } 31-50 \text { years should consume approximately } 1 \text { 1/2 cups of fruit and } 21 / 2 \text { cups } \\
\text { of vegetables per day [20]. }\end{array}$ \\
\hline & $\begin{array}{l}\text { - Following nutritional guidelines is associated with maintaining a healthy weight and reduces the } \\
\text { risk for cardiovascular diseases, some cancers, and diabetes [4]. }\end{array}$ \\
\hline & $\begin{array}{l}\text { - Despite over } 20 \text { years of promotion of fruit and vegetable consumption, in } 2009 \text { only } 23.5 \% \text { of US } \\
\text { adults consumed the daily recommended servings of fruits and vegetables [14]. }\end{array}$ \\
\hline & $\begin{array}{l}\text { - Hispanics report higher levels of fruit consumption (37.2\%) than white non-Hispanics (31.1 \%) but } \\
\text { lower levels of vegetable consumption (19.7\% vs. } 27.7 \%) \text { [44]. }\end{array}$ \\
\hline & $\begin{array}{l}\text { - Multiple environmental and sociocultural factors appear to contribute to this disparity, including } \\
\text { acculturation and the food environment of Hispanic communities [45, 46], with poor access to } \\
\text { healthy foods and grocery stores but high access to fast food options [47]. }\end{array}$ \\
\hline \multirow[t]{3}{*}{ Avoid Heavy Alcohol Use } & $\begin{array}{l}\text { - US Dietary Guidelines recommend that alcohol be consumed only in moderation, a maximum of } \\
\text { two drinks for men and one drink for women per day [48]. }\end{array}$ \\
\hline & $\begin{array}{l}\text { - One alcoholic drink is equal to } 12 \mathrm{oz} \text { of beer, } 5 \mathrm{oz} \text { of wine, or } 1.5 \mathrm{oz} \text { of distilled spirits [49]. Moderate } \\
\text { or excessive consumption of alcohol is associated with acute myocardial infarction [50], cancers of } \\
\text { the mouth, esophagus, liver, colon, and breast [51], hypertension, alcoholic cardiomyopathy, and } \\
\text { cerebrovascular events [52]. It is the nation's third-leading lifestyle related cause of death [53]. }\end{array}$ \\
\hline & $\begin{array}{l}\text { - Hispanics report lower rates of heavy drinking (6.1\%) than Native Americans (12.1\%) or whites } \\
\text { (8.3\%), but Hispanic males report the highest levels of daily heavy drinking (40\%) of all groups } \\
\text { (Native Americans } 29.34 \% \text {, whites } 30.74 \%) \text { [54]. }\end{array}$ \\
\hline
\end{tabular}


BRFSS is a national on-going telephone survey of selfreported health conducted yearly by the Centers for Disease Control and Prevention [10]. Data were collected over a 12 month period in 2009 for all states and territories of the United States [10]. For this study, the sample was restricted to respondents self-identified as Hispanic. Identification of Hispanic subgroups by country of ancestral descent is unavailable via BRFSS, but, $63 \%$ of Hispanics nationwide identify as of Mexican descent [10].

The CCHC, a prospective cohort study, began in 2004 and includes adults aged 18 years and older living in Brownsville, TX, a low-economic midsize city along the US-Mexico border with a population that is $93.2 \%$ Hispanic, with $86.2 \%$ of Mexican descent [12]. Cohort participants were recruited from randomly selected households using a two-stage cluster systematic sampling method. Participants received clinical examinations, answered a behavioral health questionnaire, and had anthropometric measures taken; a description of these has been previously published elsewhere [11]. Surveys were conducted in the participant's preferred language (English or Spanish) by trained bilingual staff. Data on tobacco use, physical activity, fruit and vegetable consumption, and alcohol use were drawn from participants' behavioral measures. Participants of Mexican descent were identified by ancestry variables when a participant, parent, or grandparent indicated nativity in Mexico. The Committee for the Protection of Human Subjects at the University of Texas Health Science Center at Houston approved all protocols and consent forms.

\section{Smoke-free living}

To assess the prevalence of smoke-free living, $\mathrm{CCHC}$ participants were asked, "Do you now smoke cigarettes?" with a response of "yes" labeled as smoker and "no" labeled as nonsmoker. BRFSS respondents were asked, "Do you now smoke cigarettes every day, some days, or not at all?" with "every day" and "some days" responses collapsed to indicate a smoker, and a response of "not as all" labeled as nonsmoker [15].

\section{Physical activity}

To assess the extent of physical activity, CCHC participants were assessed using validated scales to examine moderate and vigorous physical activity of at least 10-minute bouts during the past 7 days $[16,17]$. On the BRFSS, respondents reported the number of days per week and the total time per day of moderate and vigorous physical activity of at least 10 minute bouts [15]. CCHC and BRFSS survey items were used to estimate metabolic equivalents (METs) minutes of energy expenditure in the past 7 days, where participants with $>600$ MET adjusted minutes were considered to meet physical activity guidelines.

\section{Fruit and vegetable consumption}

Using the Two-item Food Frequency Questionnaire [18], fruit and vegetable consumption was assessed in the $\mathrm{CCHC}$ by asking participants how many portions of fruit and vegetables they ate daily. A portion size was described as a $1 / 2$ cup of fresh, frozen, or canned produce or a medium-sized piece of produce. Consumption of five or more fruit and vegetable portions was considered meeting guidelines $[19,20]$. On the BRFSS, participants reported the number of servings of fruits and vegetables daily, and those who reported five or more servings per day were considered to meet guidelines [15].

\section{Heavy alcohol use}

$\mathrm{CCHC}$ participants were asked the number of alcoholic drinks (12 oz. beer, 8 oz. wine cooler, $4 \mathrm{oz}$. wine, or $1 \mathrm{oz}$. liquor) consumed each week. The total was divided by 7 to obtain an estimated daily number of alcoholic drinks consumed. In the BRFSS, one alcoholic drink was measured as a $12 \mathrm{oz}$. beer, a $5 \mathrm{oz}$. glass of wine, or one shot of liquor [15]. For both samples, heavy alcohol use for males was identified as having more than two drinks per day and for females having more than one drink per day [15].

\section{Sociodemographic variables}

Data on age, gender, educational attainment (high school diploma or less than high school diploma) employment (employed or unemployed), preferred language (English or Spanish), and health insurance (insured or uninsured) were calculated on both samples.

\section{Statistical analysis}

To derive representative population-based estimates, all analyses were performed using sampling weights for the $\mathrm{CCHC}$ and the BRFSS samples. The two samples were compared based on sociodemographic characteristics and preventive health behaviors using generalized estimating equations (GEE) correlated outcomes to account for potential clustering among participants within $\mathrm{CCHC}$ households and census tracts and blocks. Specifically, to compare proportions by dataset (CCHC or BRFSS) and obtain crude and adjusted p-values, we used univariate and multivariate GEE regression models, respectively, with logit link function for binomial responses. Similarly, to compare means by dataset and obtain crude and adjusted p-values, we used univariate and multivariate GEE regression models with identity link function for continuous responses. All statistical tests were twosided with a significance level of 0.05. Analyses were performed using SAS version 9.1 [21].

\section{Results}

On average, sampled participants from the $\mathrm{CCHC}$ were significantly older than BRFSS participants (CCHC: 
47.22 \pm 1.0 BRFSS: $40.47 \pm 0.2$, p-value $<0.0001$ ) (Table 2). The CCHC sample also had a higher proportion of females than the BRFSS sample (CCHC: $58.3 \%$, BRFSS: $49.7 \%$, p-value $<0.0004$ ), and a higher percentage of participants who did not graduate from high school (CCHC: 47.9 \%, BRFSS: $31.2 \%$, p-value < 0.0001). Among CCHC participants, the percentage employed was significantly lower than among BRFSS participants (CCHC: $47.6 \%$, BRFSS: $55 \%$, p-value $=0.0041)$. When stratified by gender, there were fewer employed males (CCHC: $63.8 \%$, BRFSS:

Table 2 Sociodemographic characteristics of CCHC (2008-2011) and BRFSS (2009) Hispanic respondents

\begin{tabular}{|c|c|c|c|}
\hline & $\mathrm{CCHC}$ & BRFSS & Difference \\
\hline & $\begin{array}{l}n=1408 \\
n(\%) \text { or Mean } \pm \text { SE }\end{array}$ & $\begin{array}{l}n=29942 \\
n(\%) \text { or Mean } \pm \text { SE }\end{array}$ & ( $p$ value) \\
\hline \multicolumn{4}{|l|}{ All Participants } \\
\hline Mean Age & $47.22 \pm 1.0$ & $40.47 \pm 0.2$ & $<0.0001$ \\
\hline \multicolumn{4}{|l|}{ Gender } \\
\hline Male & $446(41.7)$ & $10817(50.3)$ & 0.0004 \\
\hline Female & $961(58.3)$ & $19125(49.7)$ & \\
\hline \multicolumn{4}{|l|}{ Educational Attainment } \\
\hline High School Diploma & $635(52.1)$ & $20639(68.8)$ & $<0.0001$ \\
\hline $\begin{array}{l}<\text { High School } \\
\text { Diploma }\end{array}$ & $772(47.9)$ & $9064(31.2)$ & \\
\hline \multicolumn{4}{|l|}{ Employment } \\
\hline Employed & $680(47.6)$ & $14552(55.0)$ & 0.0041 \\
\hline Unemployed & $727(52.4)$ & $15129(45.0)$ & \\
\hline \multicolumn{4}{|l|}{ Language } \\
\hline English & $295(26.7)$ & $15098(52.6)$ & $<0.0001$ \\
\hline Spanish & $1093(73.3)$ & $12362(47.4)$ & \\
\hline \multicolumn{4}{|l|}{ Insurance } \\
\hline Insured & $435(38.5)$ & $16907(65.2)$ & $<0.0001$ \\
\hline Uninsured & $961(61.5)$ & $7144(34.8)$ & \\
\hline \multicolumn{4}{|l|}{ Males } \\
\hline Mean Age & $45.3 \pm 1.6$ & $39.7 \pm 0.3$ & 0.0019 \\
\hline $\begin{array}{l}\text { Less than H.S. } \\
\text { graduate }\end{array}$ & $213(43.3)$ & 3244 (31.5) & 0.0049 \\
\hline Currently employed & $299(63.8)$ & $6398(65.6)$ & 0.6493 \\
\hline Surveyed in Spanish & $325(67.3)$ & $4394(46.9)$ & $<0.0001$ \\
\hline Has insurance & $162(38.8)$ & $6033(63.6)$ & $<0.0001$ \\
\hline \multicolumn{4}{|l|}{ Females } \\
\hline Mean Age & $48.6 \pm 1.3$ & $41.2 \pm 0.2$ & $<0.0001$ \\
\hline $\begin{array}{l}\text { Less than H.S. } \\
\text { graduate }\end{array}$ & $559(51.2)$ & $5820(31.0)$ & $<0.0001$ \\
\hline Currently employed & $381(36.0)$ & $8154(44.3)$ & 0.0017 \\
\hline Surveyed in Spanish & 768 (77.6) & 7968 (47.8) & $<0.0001$ \\
\hline Has insurance & $273(38.3)$ & $10874(66.9)$ & $<0.0001$ \\
\hline
\end{tabular}

CCHC, Cameron County Hispanic Cohort; BRFSS, Behavioral Risk Factor Surveillance System
$65.6 \%$, p-value 0.6493) and fewer employed females (CCHC: $36.0 \%$, BRFSS: $44.3 \%$, p-value $=0.0017$ ) in the $\mathrm{CCHC}$ sample.

Table 3 summarizes the preventive health behaviors of smoke-free living, meeting physical activity guidelines, fruit and vegetable consumption, and avoiding heavy alcohol use. After adjusting for age, educational attainment, employment, preferred language, and insurance, BRFSS respondents were significantly more likely than $\mathrm{CCHC}$ participants to meet recommended physical activity guidelines $(44.14 \%$ vs. $33.3 \%$, adjusted $p$-value $=0.0186)$. BRFSS respondents were also significantly more likely than $\mathrm{CCHC}$ participants to meet fruit and vegetable consumption guidelines ( $21.93 \%$ vs. $14.8 \%$, adjusted p-value $=<0.0001)$.

Table 4 summarizes preventive health behaviors stratified by gender for both samples. When adjusted for age, educational attainment, employment, preferred language, and insurance, BRFSS male respondents were significantly more likely than $\mathrm{CCHC}$ male participants to meet fruit and vegetable consumption guidelines (46.61\% vs. $39.8 \%$, adjusted p-value $=0.0034)$. BRFSS male respondents were also significantly more likely to avoid heavy alcohol use $(93.86 \%$ vs. $91.0 \%$, adjusted p-value $=$ 0.0236). Among females, BRFSS respondents were significantly more likely to meet physical activity guidelines $(41.68 \%$ vs. $39.8 \%$, adjusted p-value $=0.0015)$ and to consume adequate fruits and vegetables $(25.16 \%$ vs. $11.4 \%$, adjusted $\mathrm{p}$-value $=0.0417$ ).

Table 3 Preventive Health Behaviors of ncds among CCHC (2008-2011) and BRFSS (2009) Hispanics respondents

\begin{tabular}{lllll}
\hline $\begin{array}{l}\text { Preventive health } \\
\text { behaviors }\end{array}$ & $\begin{array}{l}\text { CCHC } \\
\mathrm{n}=1408 \\
\mathrm{n}(\%)\end{array}$ & $\begin{array}{l}\text { BRFSS } \\
\mathrm{n}=29942 \\
\mathrm{n}(\%)\end{array}$ & $\begin{array}{l}\text { Difference } \\
(\mathrm{p} \text { value) })\end{array}$ & $\begin{array}{l}\text { Adjusted } \\
(\mathrm{p} \text {-value })\end{array}$ \\
\hline $\begin{array}{l}\text { Smoke-free Living } \\
\text { Smoker }\end{array}$ & $186(16.15)$ & $4132(14.72)$ & 0.4493 & 0.3640 \\
$\begin{array}{l}\text { Non-smoker } \\
\text { Meet PA Guidelines }\end{array}$ & $1097(83.9)$ & $25383(85.28)$ & & \\
Yes & $410(33.3)$ & $10982(44.14)$ & $<0.0001$ & 0.0186 \\
No & $970(66.7)$ & $15797(55.86)$ & & \\
$\begin{array}{l}\text { Meet F\&V Consumption } \\
\text { Guidelines }\end{array}$ & & & & \\
Yes & $198(14.8)$ & $6358(21.93)$ & $<0.0001$ & $<0.0001$ \\
No & $1024(85.2)$ & $21689(78.07)$ & &
\end{tabular}

Avoid Heavy

Alcohol Use

Heavy Use

$50(4.7) \quad 884(4.38) \quad 0.6966 \quad 0.0656$

No Heavy Use

1027 (95.3) 27538 (95.62)

${ }^{1}$ Calculated adjusted $\mathrm{p}$-values adjusting for age, educational attainment, employment, language, and insurance

NCDs, non-communicable diseases; CCHC, Cameron County Hispanic Cohort; BRFSS, Behavioral Risk Factor Surveillance System; PA, physical activity; F\&V, fruits and vegetables 
Table 4 Preventive Health Behaviors of NCDs among CCHC (2008-2011) and BRFSS Hispanics respondents (2009) by gender

\begin{tabular}{|c|c|c|c|c|}
\hline & $\mathrm{CCHC}$ & BRFSS & Difference & Adjusted \\
\hline & $\begin{array}{l}n=1408 \\
n(\%)\end{array}$ & $\begin{array}{l}n=29942 \\
n(\%)\end{array}$ & (p-value) & $p$-value \\
\hline \multicolumn{5}{|l|}{ Males } \\
\hline \multicolumn{5}{|c|}{ Smoke-free Living } \\
\hline Smoker & $109(27.0)$ & 1968 (19.69) & 0.0191 & 0.1595 \\
\hline Non-smoker & $306(73.0)$ & $8672(80.31)$ & & \\
\hline \multicolumn{5}{|c|}{ Meet PA Guidelines } \\
\hline Yes & $155(39.8)$ & $4319(46.61)$ & 0.1097 & 0.8075 \\
\hline No & $283(60.2)$ & $5333(53.39)$ & & \\
\hline \multicolumn{5}{|c|}{$\begin{array}{l}\text { Meet F\&V Consumption } \\
\text { Guidelines }\end{array}$} \\
\hline Yes & $42(11.4)$ & $1821(18.71)$ & 0.0256 & 0.0034 \\
\hline No & $347(88.6)$ & $8262(81.29)$ & & \\
\hline \multicolumn{5}{|l|}{ Avoid Heavy } \\
\hline \multicolumn{5}{|l|}{ Alcohol Use } \\
\hline Heavy Use & $42(9.0)$ & $501(6.14)$ & 0.0907 & 0.0236 \\
\hline No Heavy Use & $322(91.0)$ & $9581(93.86)$ & & \\
\hline \multicolumn{5}{|l|}{ Females } \\
\hline \multicolumn{5}{|c|}{ Smoke-free Living } \\
\hline Smoker & $77(8.1)$ & 2164 (9.68) & 0.3624 & 0.8947 \\
\hline Non-smoker & 791 (91.9) & $16711(90.32)$ & & \\
\hline \multicolumn{5}{|c|}{ Meet PA Guidelines } \\
\hline Yes & $155(39.8)$ & $6663(41.68)$ & 0.1097 & 0.0015 \\
\hline No & $283(60.2)$ & 10464 (58.34) & & \\
\hline \multicolumn{5}{|c|}{$\begin{array}{l}\text { Meet F\&V Consumption } \\
\text { Guidelines }\end{array}$} \\
\hline Yes & $42(11.4)$ & $4537(25.16)$ & 0.0256 & 0.0417 \\
\hline No & $347(88.6)$ & $13427(74.84)$ & & \\
\hline \multicolumn{5}{|l|}{ Avoid Heavy } \\
\hline \multicolumn{5}{|l|}{ Alcohol Use } \\
\hline Heavy Use & $8(1.6)$ & $383(2.63)$ & 0.2703 & 0.7754 \\
\hline No Heavy Use & 675 (98.4) & 17957 (97.37) & & \\
\hline
\end{tabular}

${ }^{1}$ Calculated adjusted $\mathrm{p}$-values adjusting for age, educational attainment, employment, language, and insurance

NCDs, non-communicable diseases; CCHC, Cameron County Hispanic Cohort; BRFSS, Behavioral Risk Factor Surveillance System; PA, physical activity; F\&V, fruits and vegetables

\section{Discussion}

This study found Hispanics nationally and Hispanics living on the US-Mexico border reported low engagement in preventive health behaviors, and Hispanics living on the border engaged the least. These findings are important since Hispanics are the fastest growing population in the US and thus will influence future wellness projections and health care costs. Previous reports on disease rates from the US-Mexico border have shown significantly higher rates of overweight, obesity, and diabetes than in national samples $[9,10,22,23]$. The results of this study suggest that the population along the USMexico border will continue to have higher levels of NCDs. The study found that Hispanics living on the USMexico border were significantly less likely to engage in the preventive health behaviors of physical activity and fruit and vegetable consumption than Hispanics nationally. Also Hispanic males nationally were significantly more likely than Hispanic males on the US-Mexico border to avoid heavy alcohol use.

The limitations of this study include differences in data collection and sampling between the two datasets. In-person interviews were used to collect behavioral information from participants in the $\mathrm{CCHC}$, while BRFSS data were collected through telephone interviews. This difference introduced potentially different respondent interviewer biases since they did not sit face-to-face during the BRFSS interviews as they did in the CCHC study. However, wording of questions was similar for both samples and coding for preventive behaviors of interest was standardized in the analysis.

It should also be noted that the majority of $\mathrm{CCHC}$ participants were of Mexican descent, while BRFSS respondents were probably more diverse in their representation of Latin-descent populations. However, while past research on preventive health behaviors has shown differences between Latin descent populations in alcohol use [24-26], tobacco use [27-30], and physical activity [31-33], there are larger differences between this group and other racial/ethnic groups [32-37]. A final limitation to this study is the possible under-sampling of those with severe disparities among BRFSS participants resulting from the intent of BRFSS to produce results generalizable to the entire US. When considering national surveys, it is thus important to pay attention to under-sampled, understudied, but highly disparate areas such as the US-Mexico border.

\section{Conclusions}

Despite its limitations the study provides clear evidence of disparities in preventive health behaviors for NCDs among Hispanics along the US-Mexico border. The lack of preventive health behaviors among Hispanics along the border is particularly disturbing because it mirrors features found among low and middle income populations worldwide, where NCDs are escalating [3]. High rates of poverty among the rapidly growing population along the US-Mexico border, low levels of educational attainment, and lack of health insurance increase the complexity of addressing NCDs. Common obstacles faced in addressing disparities in preventative health behaviors include food insecurity, abundant access to unhealthy foods, and insufficient environmental infrastructure to promote preventive behaviors [38]. Our findings suggest that health resources 
should be used to disseminate and implement evidencebased practices, programs, and policies to promote preventive behaviors. A multipronged approach would span the ecological model [39] such that preventive health behaviors could be aligned with system and policy changes to support individuals in adopting and maintaining such behaviors long-term. Our findings also suggest a need for synergistic approaches to nurturing multiple preventive behaviors, rather than addressing each one as an isolated behavior. Given the disparities found in NCDs faced by Hispanics nationally and on the US Mexico border, particularly, multipronged approaches to foster preventive health behaviors are overdue.

\section{Competing interests}

The authors declare that they have no competing interests.

\section{Authors' contributions}

$\mathrm{BR}$, JW, and JM conceptualized the study. BR, SF, and JM directed data collection. BR drafted the manuscript. JW, SF, AB, and JM assisted in drafting the manuscript. KV conducted statistical analyses and drafted the analysis section. All authors read and approved the final manuscript.

\section{Acknowledgements}

This work was supported by MD000170 P20 through funding from the National Center on Minority Health and Health disparities (NCMHD), UTHealth CTSA (UL1 TR000371.

The authors of this manuscript would like to acknowledge our community partners and Community Advisory Board members, who are dedicated to eliminating health disparities. We would also like to acknowledge our professional study personnel, including Lisa Mitchell-Bennett, Vanessa Saldaña, Kendra Stine, Alejandra Esparza, Pablo Sanchez, Maria Perez, Julie Orta, Alfredo Hernandez, Julie Gomez-Ramirez, and Christina Villarreal, as well as Rose Gowen, MD, for her supervision of the Clinical Research Unit. Thank you to Valley Baptist Health System for space for the Clinical Research Unit. We are particularly thankful to our participants - the citizens of Brownsville who so generously and willingly gave and still give their cooperation and time.

\section{Author details}

'University of Texas Health Science Center - School of Public Health, Brownsville Regional Campus, One West University Blvd, RAHC, Brownsville, TX 78520, USA. 'University of Texas Health Science Center at Houston School of Nursing, 6901 Bertner, Houston, TX 77030, USA. ${ }^{3}$ University of Texas Health Science

Center - School of Public Health, Austin Regional Campus, 1616 Guadalupe, Suite 6.300, Austin, TX 78701, USA.

\section{Received: 8 October 2014 Accepted: 19 May 2015}

Published online: 19 June 2015

\section{References}

1. World Health Organization. Global status report on noncommunicable diseases 2010. Description of the global burden of NCDs, their risk factors and determinants. World Health Organization. 2011. http://www.who.int/ nmh/publications/ncd_report2010/en/. Accessed 15 Jan 2014.

2. Bloom DE, Cafiero ET, Jane-Llopis E, Abrahams-Gessel S, Bloom LR, Fathima S, et al. The global economic burden of noncommunicable diseases. Geneva: World Economic Forum; 2011.

3. World Health Organization. A prioritized research agenda for prevention and control of noncommunicable diseases. Geneva: World Health Organizaton; 2011. http://www.who.int/cardiovascular_diseases/ publications/ncd_agenda2011/en/. Accessed 15 Jan 2014.

4. Center for Disease Control and Prevention. The Power of Prevention: Chronic Disease... the public health challenge of the 21st century. Center for Disease Control and Prevention. 2009. http://www.cdc.gov/ chronicdisease/pdf/2009-Power-of-Prevention.pdf. Accessed 2 August 2014.
5. Kung HC. Deaths: Final Data for 2005. Hovert DL, Xu J, Murphy SL, Deaths: final data for 2005, Natl Vital Stat Rep. 2008; 56(10):1-120.

6. Lloyd-Jones D, Adams R, Carnethon M, De Simone G, Ferguson TB, Flegal K, et al. American Heart Association Statistics Committee and Stroke Statistics Subcommittee. Heart Disease and Stroke Statistics - 2009 Update A Report from the American Heart Association Statistics Committee and Stroke Statistics Subcommittee. Circulation. 2009;119:E21-E181.

7. Center for Disease Control and Prevention. Unite States-Mexico Public Health: About the Border Region. Centers for Disease Control and Prevention. 2013. http://www.cdc.gov/usmexicohealth/about-border-region.html Accessed 2 August 2014.

8. Fisher-Hoch SP, Vatcheva KP, Laing ST, Hossain MM, Rahbar MH, Hanis $C L$, et al. Missed Opportunities for Diagnosis and Treatment of Diabetes, Hypertension, and Hypercholesterolemia in a Mexican American Population, Cameron County Hispanic Cohort, 2003-2008. Preventing Chronic Disease 2012;9:110298

9. Ennis S, Rios-Vargas M, Albert N. The Hispanic Population: 2010. 2010 Census Briefs . 2011. United States Census Bureau. 2011. https://www.census.gov/ prod/cen2010/briefs/c2010br-04.pdf. Accessed 2 August 2014.

10. Li C, Balluz LS, Okoro CA, Strine TW, Lin JM, Town M, et al. Centers for Disease Control and Prevention (CDC). Surveillance of certain health behaviors and conditions among states and selected local areas Behavioral Risk Factor Surveillance System, United States, 2009. MMWR Surveill Summ. 2011;60(9):1-250.

11. Fisher-Hoch SP, Rentfro AR, Salinas JJ, Perez A, Brown HS, Reininger BM, et al. Socioeconomic status and prevalence of obesity and diabetes in a Mexican American community, Cameron County, Texas, 2004-2007. Prev Chronic Dis. 2010;7(3):A53.

12. U.S. Census Bureau. Profile America: Facts for Features: Hispanic Heritage Month 2012: Sept. 15-Oct. 15. U.S. Census Bureau News. 2012. https:// www.census.gov/newsroom/releases/archives/facts_for_features_special_ editions/cb12ff19.html. Accessed 1 August 2014.

13. U.S. Census Bureau. American FactFinder. Race and Hispanic or Latino Origin. 2010 Census Summary File 1. U.S. Census Bureau. 2010. http:// factfinder.census.gov/faces/tableservices/js/pages/productview.xhtml? src=bkmk. Accessed 1 August 2014

14. Center for Disease Control and Prevention. Behavioral Risk Factor Surveillance System Survey Data: prevalence and trends data. 2009.

15. Centers for Disease Control and Prevention. Calculated Variables in the 2009 Behavioral Risk Factor Surveillance System Data File. Centers for Disease Control and Prevention. 2010. http://www.cdc.gov/brfss/annual_data/2009/ pdf/calcvar_09.pdf.. Accessed 15 Sept 2014.

16. Godin G, Shephard RJ, Craig CL, Marshall AL, Sjostrom M, Bauman AE, et al. International physical activity questionnaire: 12-country reliability and validity. Med Sci Sports Exerc. 2003;35:1381-1395.

17. Godin G, Shephard RJ. Godin leisuretime exercise questionnaire. Med Sci Sports Exerc. 1997;29:S36-8

18. Cappuccio FP, Rink E, Perkins-Porras L, Mckay C, Hilton S, Steptoe A. Estimation of fruit and vegetable intake using a two-item dietary questionnaire: a potential tool for primary health care workers. Nutr Metab Cardiovasc Dis. 2003:13:12-19.

19. US Department of Agriculture. Choose My Plate, Food Groups. 2013. US Department of Agriculture. http://www.choosemyplate.gov/foodgroups/ Accessed 1 August 2014

20. US Department of Agriculture. Choose My Plate, Vegetables. 2013. US Department of Agriculture. http://www.choosemyplate.gov/foodgroups/ vegetables.html. Accessed 1 August 2014.

21. SAS [ Version SAS 9.1.3. Cary, NC: SAS Institute, Inc; 2000.

22. Mier N, Medina AA, Ory MG. Mexican Americans with type 2 diabetes: perspectives on definitions, motivators, and programs of physical activity. Prevent Chronic Dis. 2007;4(2).

23. Mier N, Smith ML, Irizarry D, Carrillo-Zuniga G, Lee C, Trevino L, Ory MG. Bridging research and policy to address childhood obesity among border Hispanics a pilot study. Am J Prev Med. 2013;44:S208-S214.

24. Nielsen AL. Examining drinking patterns and problems among Hispanic groups: Results from a national survey. J Stud Alcohol. 2000;61:301-10.

25. Ramisetty-Mikler S, Caetano R, Rodriguez LA. The Hispanic Americans baseline alcohol survey (HABLAS): alcohol consumption and sociodemographic predictors across hispanic national groups. J Substance Use. 2010;15:402-16. 
26. Randolph WM, Stroup-Benham C, Black SA, Markides KS. Alcohol use among Cuban-Americans, Mexican-Americans, and Puerto Ricans. Alcohol Health Res World. 1998;22:265-9.

27. Caraballo RS, Yee SL, Gfroerer J, Mirza SA. Adult Tobacco Use Among Racia and Ethnic Groups Living in the United States, 2002-2005. Preventing Chronic Disease 2008:5(3):A78.

28. Kaplan RC, Bangdiwala SI, Barnhart JM, Castaneda SF, Gellman MD, Lee DJ, Perez-Stable MD, Talavera GA, Youngblood ME, Giachello AL. Smoking among US Hispanic/Latino adults the hispanic community health study/study of latinos. Am J Prev Med. 2014:46:496-506.

29. Morales LS, Lara M, Kington RS, Valdez RO, Escarce JJ. Socioeconomic, cultural, and behavioral factors affecting Hispanic health outcomes. J Health Care Poor Underserved. 2002;13(4):477-503.

30. Perez-Stable EJ, Ramirez A, Villareal R, Talavera GA, Trapido E, Suarez L, Marti J McAlister A. Cigarette smoking behavior among US Latino men and women from different countries of Origin. Am J Public Health. 2001;91(9):1424-30.

31. Neighbors CJ, Marquez DX, Marcus BH. Leisure-time physical activity disparities among Hispanic subgroups in the United States. Am J Public Health. 2008;98:(8)1460-4.

32. Marquez DX, Neighbors CJ, Bustamante EE. Leisure time and occupational physical activity among racial or ethnic minorities. Med Sci Sports Exerc. 2010;42(6):1086-93.

33. Zsembik BA, Fennell D. Ethnic variation in health and the determinants of health among Latinos. Soc Sci Med. 2005;61(1):53-63.

34. Dawson DA. Beyond black, white and hispanic: race, ethnic origin and drinking patterns in the united states. J Subst Abus. 1998;10(4):321-39.

35. Caetano R, Baruah J, Ramisetty-Mikler S, Ebama MS. Sociodemographic predictors of pattern and volume of alcohol consumption across Hispanics, Blacks, and Whites: 10-year trend (1992-2002). Alcohol Clin Exp Res. 2010;34(10):1782-92.

36. Giovino GA, Schooley MW, Zhu BP, Chrisomn JH, Tomar SL, Peddicord JP, et al. Surveillance for selected tobacco-use behaviors - United States, 1900-1994. MMWR CDC Surveill Summ. 1994; 43(3).

37. Caetano R, Clark CL. Trends in alcohol consumption patterns among whites, blacks and Hispanics: 1984 and 1995. J Stud Alcohol. 1998;59(6):659-68.

38. World Health Organization. Diet, nutrition, and the prevention of chronic diseases: report of a joint WHO/FAO expert consultation. WHO technical report series 916. Geneva: World Health Organizations; Food and Agriculture Organization; 2002.

39. McLeroy KR, Bibeau D, Steckler A, Glanz K. An ecological perspective on health promotion programs. Health Educ Behav. 1988;15(4):351-77.

40. Center for Disease Control and Prevention. Smoking-Attributable Mortality, Years of Potential Life Lost, and Productivity Losses -- United States, 2000-2004. MMWR 2008 57(45), 1226-1228. Center for Disease Control and Prevention

41. Center for Disease Control and Prevention. Tobacco use among adults -- United States, 2005. MMWR 2006 55[42], 1145-1148. Center for Disease Control and Prevention.

42. Carlson SA, Fulton JE, Galuska DA, Kruger J, Lobelo F, Loustalot FV. Prevalence of self-reported physically active adults-United States, 2007 (reprinted from MMWR, vol 57, pg 1297-1300, 2008). Jama-J Am Med Assoc. 2009;301:926-7.

43. Center for Disease Control and Prevention. Physical Activity for Everyone. 2011. Center for Disease Control and Prevention. http://www.cdc.gov/ physicalactivity/everyone/guidelines/index.html. Accessed 25 August 2014.

44. Center for Disease Control and Prevention. State-specific trends in fruit and vegetable consumption among adults -- united states, 2000-2009. Morbidity Mortality Report. 2010;59:1125-30.

45. Ghaddar S, Brown CJ, Pagan JA, Diaz V. Acculturation and healthy lifestyle habits among hispanics in united states-mexico border communities. Revista Panamericana Salud Publica-Pan Am J Public Health. 2010;28:190-7.

46. Ford PB, Dzewaltowski DA. Disparities in obesity prevalence due to variation in the retail food environment: three testable hypotheses. Nutr Rev. 2008;66:216-28.

47. Larson NI, Story MT, Nelson MC. Neighborhood environments disparities in access to healthy foods in the US. Am J Prev Med. 2009;36(1):74-81.

48. U.S.Department of Health and Human Services. Dietary guidelines for americans, 2010. Edited by U.S.Department of agruiculture and U.S.Department of health and human services. Washington, D.C., U.S: Government Printing Office; 2010

49. National Institute on Alcohol Abuse and Alcoholism. Alcohol and the Hispanic Community. National Institute on Alcohol Abuse and Alcoholism.
2011. http://pubs.niaaa.nih.gov/publications/HispanicFact/hispanicFact.pdf. Accessed 1 September 2014.

50. Naimi TS, Brewer RD, Mokdad A, Denny C, Serdula MK, Marks JS. Binge drinking among US adults. Jama-J Am Med Assoc. 2003;289(1):70-5.

51. Baan R, Straif K, Grosse Y, Secretan B, El Ghissassi F, Bouvard V, et al. Carcinogenicity of alcoholic beverages. Lancet Oncol. 2007;8(4):292-3.

52. Kloner RA, Rezkalla SH. To drink or not to drink? That is the question. Circulation. 2007;116(11):1306-17.

53. Caetano R, Cunradi C. Alcohol dependence: a public health perspective. Addiction. 2002;97(6):633-45.

54. Chartier K, Caetano R. Ethnicity and health disparities in alcohol research. Alcohol Res Health. 2010;33(1-2):152-60

\section{Submit your next manuscript to BioMed Central and take full advantage of:}

- Convenient online submission

- Thorough peer review

- No space constraints or color figure charges

- Immediate publication on acceptance

- Inclusion in PubMed, CAS, Scopus and Google Scholar

- Research which is freely available for redistribution 